\title{
REIMAJINASI POLITIK DALAM NOVEL RABET, RUNTUHNYA JERMAN TIMUR KARYA MARTIN JANKOWSKI
}

\author{
Akhmad Taufiq \\ FKIP Universitas Jember \\ email: akhmadtaufiq1@gmail.com
}

\begin{abstract}
Abstrak
Penelitian ini bertujuan mendeskripsikan faktor penyebab, proses rekonstruksi ideologi, dan proses reimajinasi politik pada fenomena kebangsaan bersatunya kembali Jerman sebagai satu bangsa dan negara. Sumber data penelitian adalah novel Rabet, Runtuhnya Jerman Timur karya Martin Jankowski. Penelitian menggunakan perspektif studi new historicism dengan tiga langkah analisis, yakni: dimensi ideologi, praktik diskursif pada saat peristiwa terjadi, dan praktik diskursif dalam konteks kekinian. Hasil penelitian menunjukkan bahwa bersatunya kembali Jerman sebagai sebuah bangsa didasari tiga hal berikut. Pertama, hadirnya kesadaran dalam diri masyarakat Jerman Timur dan Jerman Barat untuk hidup bersama, setelah berpuluh-puluh tahun berpisah. Kedua, kesadaran atas pentingnya rekonstruksi ideologi bagi negara yang dibangun, yakni hadirnya ideologi alternatif politik jalan ketiga. Ketiga, reimajinasi politik yang didorong kesadaran berdimensi ras yang memungkinkan tumbuhnya kebebasan, nihilnya tindakan kekerasan, dan terpenuhinya kesejahteraan merupakan cita-cita ideal yang diimpikan.
\end{abstract}

Kata kunci: reimajinasi politik, rekonstruksi ideologi, dan new historicism

\section{POLITICAL REIMAGINATION IN RABET, RUNTUHNYA JERMAN TIMUR A NOVEL BY MARTIN JANKOWSKI}

\begin{abstract}
This study aims to describe the factors, ideological reconstruction process, and political reimagination process in a nationhood phenomenon of the reunification of Germany as a nation and a state. The data source was Rabet, Runtuhnya Jerman Timur, a novel by Martin Jankowski. The study employed the perspective of new historicism studies through three steps of analysis, namely the ideological dimension, discursive practice at the time the events occurred, and discursive practice in the present context. The results of the study suggest that the reunification of Germany as a nation is based on three factors, namely: (1) the presence of collective consciousness among the citizens of East Germany and West Germany to live together after they have lived apart for decades; (2) the awareness of the importance of ideological reconstruction for the country to be built, that is the presence of alternative political ideology in the third way; and (3) the political reimagination driven by racial dimension awareness enabling freedom to grow, violent acts to disappear, and welfare to be realized as envisioned ideals.
\end{abstract}

Keywords: political reimagination, ideological reconstruction, new historicism

\section{PENDAHULUAN}

Runtuhnya Jerman Timur merupakan peristiwa sejarah yang tidak mungkin di- lupakan, tidak hanya bagi warga Jerman, akan tetapi juga bagi warga seluruh dunia. Peristiwa itu sekaligus menandai adanya 
babak baru bagi negara Jerman. Setelah lebih dari empat puluh tahun sebagai negara yang dipisahkan oleh Tembok Berlin menjadi dua negara Jerman, yakni Jerman Barat yang Pro-Barat yang berideologi liberalis-kapitalis dan Jerman Timur yang berkiblat pada Uni Sovyet dan berideologi sosialis. Dua negara yang sudah berpisah selama empat puluh tahun tersebut menjadi bersatu kembali atas dorongan yang luar biasa dari warga yang berada di Jerman Timur.

Dorongan yang sampai saat ini belum banyak diperbincangkan orang; bukan hanya semata-mata kehendak untuk hidup lebih terbuka dan bebas dalam sebuah iklim negara yang bersifat demokratik, lebih dalam dari itu ada kesadaran kolektif yang muncul secara bersama antara kedua warga Jerman. Dorongan yang dilandasi oleh hadirnya kesadaran kolektif tersebut perlu dibaca dan dianalisis sebagai sebuah kemungkinan membuka ruang bersatunya suatu bangsa yang sudah pernah berpisah.

Kesadaran kolektif yang mengikat semua warga itulah hendaknya didedah aktor kebangsaan bagi terakumulasinya berbagai dorongan, wacana, dan hasrat politik yang beroperasi di dalamnya. Runtuhnya Tembok Berlin dan Jerman Timur dalam konteks tersebut hanyalah sebagai momen sejarah yang menandai bagi terakumulasinya dorongan, wacana, dan hasrat politik tadi yang sebenarnya bersifat kompleks. Tidak hanya menyangkut konteks administratif bagi sebuah negara yang sudah lebih empat puluh tahun menegakkan kampiun kuasanya; lebih dari itu, menyangkut konteks kultural yang lebih luas dan rumit sifatnya. Disebut demikian, karena bicara masalah Jerman, sama halnya bicara tentang konteks sejarah Jerman yang sangat panjang, tidak hanya dibatasi pada masa PD II; akan tetapi, rentang sejarah Jerman sebagai bangsa yang besar dan merasa unggul dibanding bangsa-bangsa yang lain, jauh sebelum PD II.
Oleh karena itu, bersatunya kembali kedua negara Jerman itu merupakan kebanggaan tersendiri warganya. Hal itu didasari oleh kenyataan tidak adanya intervensi atau bantuan negara asing dalam rangka penyatuan kembali (reunifikasi) kedua negara yang sudah empat puluh tahun lebih berpisah. Satu situasi yang tidak diperkirakan; bahkan oleh dinas rahasia Uni Sovyet KGB saat itu (Gonscharenko dan Ridwan, 2009:1). Di sisi lain, Inggris dan Prancis terang-terangan menentang penyatuan kembali negara Jerman itu. Hal tersebut logis karena terdapat kekhawatiran Jerman menjadi negara besar seperti sebelum PD II. Kesadaran kolektif dalam konteks itu dapat dibaca sebagai proses suksesnya aktivis gerakan revolusi dalam merekonstruksi ideologi dan mereimajinasi politik yang terjadi di negara Jerman Timur.

Fenomena hadirnya bangsa Jerman bersatu, yang didorong oleh adanya kesadaran kolektif, proses rekonstruksi ideologi, dan reimajinasi politik di negara Jerman Timur tersebut menarik untuk dianalisis. Sebagai sebuah peristiwa politik, fenomena bersatunya bangsa Jerman tersebut layak ditelusuri dan dijadikan kajian menarik, yang dapat memberikan kontribusi bagi bangsa lain yang memiliki pengalaman serupa.

Dalam konteks tersebut, studi new historicism relevan untuk mendedah fenomena politik dan latar belakang ideologi atas peristiwa sejarah yang demikian. Seperti yang dikemukakan Gallagher (1999:434), dimensi ideologis itulah hal yang paling dominan dalam kajian new historicism. Hal itu dapat diterima karena manusia saat ini dipandang tidak memiliki akses yang jelas pada fakta manapun, kecuali fakta yang paling dasar dari sejarah yang telah tertekstualisasikan dan fakta yang paling dasar dari sejarah itu ialah ideologi dan praktik diskursif (Barry, 2010:204).

Teks sastra dalam hubungan itu memiliki peluang menghadirkan kembali 
peristiwa sejarah bagi realitas ideologi dan praktik diskursif politik yang pernah terjadi. Realitas sejarah dipotret dan direkam sedemikian rupa agar dapat dibaca dan ditafsirkan sesuai dengan konteks zaman yang berbeda. Sehubungan dengan hal itu, novel sebagai salah satu bentuk teks sastra dimungkinkan mampu menjadi alat rekam sejarah yang relatif utuh karena mampu memotret dan merekam peristiwa sejarah berikut atmosfir kejiwaan sehingga peristiwa sejarah tersebut tampak hidup.

Novel Rabet, Runtuhnya Jerman Timur yang ditulis Martin Jankowski, dalam konteks itu mencoba memotret dan merekam dengan cukup saksama atas terjadinya peristiwa politik dan ideologi tersebut. Oleh karena itu, dalam novel tersebut digambarkan kurang lebih sama dengan kenyataan sejarah yang sebenarnya. Penyatuan kembali Jerman sebagai negara yang selama ini berpisah selama empat puluh tahun lebih itu dipotret sedemikian rupa, dengan cara membidik bagianbagian penting dalam sejarah runtuhnya Jerman Timur tersebut. Meskipun, patut diakui bahwa penulisan novel Rabet ini, dapat disebut sebagai bentuk penghargaan terhadap teman-teman aktivis gerakan revolusi, sekaligus menunjukkan adanya kenyataan tekanan psikologis dan politis bagi fakta yang terjadi saat itu. Asumsi historisnya, novel tersebut pasti sulit diterbitkan atau bahkan dilarang oleh kekuasaan politik di Jerman Timur, seandainya pemerintah Jerman Timur belum runtuh.

Oleh karena itu, novel Rabet, Runtuhnya Jerman Timur yang ditulis Martin Jankowski dapat diletakkan dalam konteks rekaman ekspresif bagi seorang penulis/sastrawan sekaligus aktivis gerakan saat itu (Jankowski, 2010:1). Tentunya, rekaman ekspresif tersebut patut dibaca sebagai representasi teks terhadap kenyataan historis yang ada; dan sebaliknya, merupakan representasi historis bagi kenyataan teks yang dikonstruksi. Dalam konsteks demikian ini, novel Rabet, Runtuhnya Jerman Timur yang ditulis Martin Jankowski, menjadi menarik untuk dianalisis. Salah satu konstruksi kajian yang dapat dilakukan yaitu dengan cara mendeskripsikannya melalui teori new historicism.

Seperti yang dikemukakan Greenblatt (2005:5), asumsi dasar teori new historicism, yakni adanya hubungan timbal-balik antara manusia dengan peradabannya. Teks dalam konteks tersebut merefleksikan pola hubungan timbal-balik antara manusia dan peradaban yang membentuknya. Bermula dari teks, begitu pula teori new historicsm juga bertolak dari teks. Sebagai teori yang bertolak dari teks, teori new historicsm memberikan pandangan khusus terkait dengan teks.

Teks yang faktanya beragam, menurut teori new historicsm tidak perlu diperlakukan pembedaan, baik itu bersifat horisontal maupun bersifat hirarkis-vertikal (Barry, 2010:201). Bagi teori new historicsm, teks dengan berbagai sumber dan variasi perlu diberikan penghargaan yang sama. Apakah itu bersumber dari proses imajinatif manusia, ataukah dari catatan yang bersifat linier perjalanan hidup manusia; semua diperlakukan secara setara dan sejajar.

Dalam konteks itu, Greenblatt (2000: 168-169) menyatakan bahwa salah satu permasalahan penting dalam konteks kajian new historicsm dan kajian budaya secara lebih luas; yakni, perilaku atau budaya yang dikukuhkan dalam teks. Sehubungan dengan itu, kajian new historicism dipandang mampu menawarkan perspektif baru, yang menekankan keterkaitan teks sastra dengan berbagai kekuatan sosial, ekonomi, dan politik yang melingkupinya (Sugiarti, 2009:165).

Teks sastra dalam konteks demikian di satu sisi dan teks sejarah sebagai catatan jejak-rekam perjalanan kehidupan manusia merupakan teks yang sejajar; diantara 
keduanya tidak berlaku proses diskriminasi, baik bersifat horisontal maupun vertikal. Sebaliknya diantara kedua jenis teks itu memiliki hubungan yang erat dan saling mengisi. Teks sejarah dalam konteks demikian tidak boleh diletakkan sebagai konteks; tetapi sebagai teks yang perlu dianalisis pula secara memadai (Barry, 2010:202). Oleh karena itu, terdapat alasan yang relevan dan logis bila teori new historicsm memosisikan secara setara teks sejarah dengan teks sastra. Dalam teks sastra, sebagai teks yang diproduksi dari ruang imajinasi manusia, dibalik itu menyimpan latar belakang historis, ideologis, politik, dan bahkan sosial-budaya. Dalam hubungan yang demikian tekstualitas historis dan historisitas teks menjadi term yang cukup memadai untuk mengakomodasi fenomena yang demikian ini (Barry, 2010:204).

Teks dan konteks dalam paparan yang demikian ini perlu dikritisi ulang. Kalau misalnya term teks dan konteks perlu diterima, maka 'konteks' dalam hubungannya dengan 'teks' perlu diletakkan sebagai teks; bukan konteks yang berada diluar teks. Baru premis yang menyatakan bahwa teori new historicsm berhubungan dengan teks dan konteks dapat diterima sebagai konstruksi yang sejajar. Menurut Brannigan (1999: 417), menyatakan bahwa teori new historicsm merupakan pendekatan yang menghubungkan antara teks dan konteks pada muatan penting atas dimensi politik secara lebih luas, hubungannya dengan interpretasi sastra. Dalam pandangan teori new historicsm, semua jenis teks merupakan upaya memediasi formasi sosial, politik, dan budaya.

Lebih lanjut, new historicsm tidaklah semata-mata membaca peristiwa tadi sebagai urutan ruang dan waktu secara linier. Peristiwa dibaca dan dipahami sebagai kejadian yang kompleks, sebagai peristiwa yang tidak terjadi begitu saja. Dibalik peristiwa atau kejadian historis itu harus dicurigai banyak hal yang melatar- belakangi. Peristiwa atau kejadian historis itu tidak cukup logis kalau dikemukakan sebagai sesuatu yang kebetulan. Tidak ada logika yang dapat diterima atas kejadian historis yang dinyatakan sebagai peristiwa yang kebetulan.

Peristiwa atau kejadian historis itu dicurigai terdapat persoalan-persoalan mendasar yang melatarinya. Persoalan mendasar yang melatari peristiwa atau kejadian historis itu, yakni persolan ideologi, politik, dan sosio-kultural. Oleh karena itu, menurut teori new historicsm, tugas akademis yang utama dalam melihat fenomena atas peristiwa historis tadi ialah membongkar dimensi ideologi, politik, dan sosio-kultural tadi. Pada saat yang sama, mencoba semaksimal mungkin untuk membuka daya operasi yang bergerak di dalamnya (Taufiq, 2012:84).

Bertolak dari paparan di atas, maka new historicsm lebih bersifat sebagai gerakan yang menyejarah (historicist movement) daripada gerakan sejarah (historical movement) (Barry, 2010:204). Dalam hubungannya dengan gerakan yang menyejarah tadi, new historicsm memandang tidak ada yang diluar teks, semua ada di dalam teks yang perlu mendapatkan analisis yang memadai. Oleh karenanya, membuka jaringan kebahasaan yang ada di dalam teks merupakan sesuatu yang urgen dilakukan. Tanpa mencoba untuk membuka jaringan kebahasaan yang ada di dalam teks, maka peristiwa sejarah dalam konteks ideologi, politik, dan sosio-kultural akan tetap saja berada di tempatnya.

Bertolak dari paparan tersebut, tulisan ini dimaksudkan untuk mendedah selubung yang terdapat dalam teks novel Rabet, Runtuhnya Jerman Timur karya Martin Jankowski dari sisi proses reimajinasi politik yang terjadi. Oleh karena itu, fokus kajian tulisan ini, yakni: (1) faktor penyebab runtuhnya Jerman Timur; (2) proses rekonstruksi ideologi warga Jerman Timur; (3) proses reimajinasi politik warga Jerman Timur yang direfleksikan 
dalam novel Rabet, Runtuhnya Jerman Timur karya Martin Jankowski.

\section{METODE}

Berdasarkan acuan teoretik, penelitian ini menggunakan pendekatan deskriptifkualitatif. Suatu pendekatan yang mengandaikan data dalam penelitian berupa kata, kalimat, dan paragraf yang sesuai dengan objek penelitian (Miles dan $\mathrm{Hu}-$ berman, 2009:15). Sumber data penelitian ini adalah novel Rabet, Runtuhnya Jerman Timur karya Martin Jankowski, diterbitkan oleh Penerbit Waktoe, 2010. Novel tersebut terjemahan dari Rabet Oder Das Verschwinden Einer Himmelsrichtung oleh Verbis Scheidegg, 1999.

Lebih lanjut, analisis dalam penelitian ini menggunakan teori new historicism. Ada tiga dimensi penting yang dilakukan dalam upaya menjelaskan fenomena sejarah melalui teks dalam teori new historicism (Barry, 2010:204). Pertama, melalui ideologi, yakni satu fase akademis untuk membuka selubung ideologi yang berada di balik teks. Kedua, melalui praktik diskursif yang terjadi pada masanya sendiri; yakni, suatu upaya untuk menjelaskan praktik-praktik diskursif yang pernah terjadi. Melalui teks, praktik diskursif itu dapat dibaca, dibongkar, dan dijelaskan secara memadai. Ketiga, melalui praktik diskursif yang terjadi saat ini, yakni ketika teks itu sudah dalam pergulatan dan pertarungan wacana dalam konteks kekinian, karena hanya melalui praktik diskursif saat ini, hal-hal substansial dan fundamental dalam dimensi kehidupan manusia itu, baru dapat dinyatakan berhubungan dengan peristiwa historis yang pernah terjadi. Ketiga hal tersebut dalam proses analisis data penelitian dilakukan secara integratif. Hal tersebut dilakukan karena antara ketiga dimensi tersebut memiliki hubungan yang tidak jarang tampak berkelindan antara satu dengan yang lainnya.

\section{HASIL DAN PEMBAHASAN}

Umumnya kajian-kajian yang menyangkut bersatunya sebuah bangsa yang telah berpisah tidak menyentuh jawaban pada faktor fundamental. Penelitian ini menunjukkan bahwa bersatunya sebuah bangsa yang telah lama berpisah, seperti halnya bangsa Jerman dilatarbelakangi oleh faktor fundamental. Persoalan kesadaran kolektif sebagai bangsa, kesadaran atas pentingnya rekonstruksi ideologi, dan reimajinasi politik mampu memberikan perspektif baru dan utuh. Perspektif baru dan utuh tersebut menyangkut bagaimana negara-bangsa dihadirkan kembali dalam ruang kesadaran, rekonstruksi ideologi, dan reimajinasi politik yang berbeda dengan kondisi sebelumnya. Sejumlah isu-isu fundamental tersebut mampu direfleksikan dengan baik dalam novel Rabet, Runtuhnya Jerman Timur karya Martin Jankowski yang mampu memotret dan merekam dengan utuh atas realitas kesadaran kolektif sebagai faktor runtuhnya Jerman Timur, rekonstruksi ideologi, dan reimajinasi politik yang terjadi.

\section{Faktor Penyebab Runtuhnya Jerman Timur}

Runtuhnya Jerman Timur, betapapun dahsyatnya tidak lepas dari potret dasar bagaimana pola hubungan negara dan rakyat (warga negara) yang terjadi. Relasi negara dan rakyat menjadi dimensi fundamental bagi sebuah pola hubungan itu. Pasca PD II, Jerman diketahui telah terpecah menjadi dua bagian, yakni Jerman Barat yang lebih Pro-Barat dan Jerman Timur yang lebih berorientasi ke Timur, atau dengan bahasa yang lugas dikontrol oleh Uni Sovyet. Proses demikian itu, berimplikasi pada kebijakan dan sikap masing-masing negara terhadap rakyatnya.

Jerman Timur sangat berambisi pula untuk mengontrol dan mengarahkan secara sangat ketat terhadap rakyatnya, untuk membangun kebudayaan Timur 
yang sosialis dan anti-Barat. Implikasi fundamental hal itu, yakni lahirnya tindakan represif negara melalui instrument suprastruktur yang dimiliki. Rakyat direpresi sedemikian rupa dan oleh karenanya kehidupan rakyat menjadi tertekan dan otomatis kebebasannya dirampas oleh negara.

Negara dalam konteks demikian, seperti yang dikemukakan Foucault menjadi serba tahu dan merasa menjadi pihak yang paling memiliki otoritas untuk mengarahkan rakyat. Itulah fenomena negara yang sudah memetamorfosa wajahnya menjadi negara panaptikon (Foucault, 1997:104). Yakni, suatu model penerapan teknologi disiplin yang keras dan ketat dalam rangka melakukan penaklukan terhadap individu warga negara.

Faktor fundamental dibalik apa yang tampak dari permukaan peristiwa politik itu, mestinya dapat ditelusuri dan dibongkar. Faktor fundamental itu terkait dengan, apa yang disebut Jung dengan ketidaksadaran bersama (collective uncounsciousness) yang bergerak ruang batin rakyat. Fenomena sejarah menurut Jung, juga bertolak dari ketidaksadaran bersama; oleh karena itu, sejarah merupakan pengulangan pengalaman manusia, wujud dari ketidaksadaran kolektif yang demikian itu (Darma, 2004:145-146). Otoriterisme negara, diduga bukanlah sebagai faktor fundamental sebagai penyebab runtuhnya negara Jerman Timur.

Sebagai suatu fenomena yang menyajikan pengalaman historis tersebut, peristiwa runtuhnya Jerman Timur perlu dibaca dan didedah untuk dapat mengungkapkan hal yang paling mendasar di balik realitas. Pengungkapan 'pengalaman' yang mendasar di balik realitas itulah yang terpenting dalam konteks menerobos esensi dari fenomena yang sebenarnya (Hogan, 2007:108). Praksisnya, maka dalam membaca fenomena runtuhnya Jerman Timur pun perlu untuk masuk pada wilayah esensi di balik kenyataan peristiwa yang tampak di permukaan sejarah.

Di bawah ini kutipan data yang dapat mendeskripsikan fenomena di balik runtuhnya negara Jerman Timur tersebut.

Di depan pintu masuk samping gereja Nikolai, Dorothee sudah menungguku. Dia berusaha menghindar agar tidak tertekan oleh arus manusia, yang menghimpitnya ke dinding gereja. Di mana-mana orang-orang meneriakkan seruan: TANPA KEKERASAN!

TANPA KEKERASAN KAMIRAKYAT BIARKAN KAMI LEWAT KAMI... Tidak ada lagi tempat. Bagaimana bisa semua orang dapat keluar dari bangunan? Apakah lebih baik menunggu di dalam? (Jankowski, 2010:218).

"Apa pendapat Anda tentang penyatuan Jerman?" Tanya seorang reporter perempuan Inggris padaku. Dia menyeretku ke sorot lampu di bawah balkon opera, sementara di atas, seorang orator perempuan dari kelompok reformasi membuat orang bersorak-sorai. Si penyihir. Gesa.

JERMAN SATU TANAH AIR JERMAN SATU TANAH AIR... teriak sekelompok lelaki dan perempuan yang mengenakan jaket kapas.

...

JERMAN SATU TANAH AIR...teriak orang-orang berjaket kapas dalam gaya stadion. Berusaha untuk jujur, untuk menghalangi agar tepuk tangan orang-orang di belakang tidak sampai ke kamera.

...

JERMAN SATU TANAH AIR JERMAN SATU TANAH AIR... "Apa sebenarnya yang telah kau ceritakan pada mereka?" Tanya seorang perempuan si jaket kapas padaku ketika aku ingin melewati barisan leher-leher yang menjerit menjulur secara diamdiam. 
“Sesuatu tentang reunifikasi," kataku singkat.

(Jankowski, 2010:254-256)

Terdapat dua hal yang patut dicatat untuk mendeskripsikan peristiwa runtuhnya Jerman Timur. Pertama, runtuhnya Jerman Timur terjadi tidaklah semata-mata karena faktor otoriter dan represifnya negara terhadap rakyat. Praktik otoriter dan represifnya negara terhadap rakyat tidak dapat dimasukkan dalam kategori penyebab fundamental. Praktik otoriter dan represifnya negara hanyalah pemantik bagi penyebab fundamental yang sebenarnya. Kedua, penyebab fundamental yang sebenarnya, yakni adanya dorongan (hasrat) yang besar dalam diri masyarakat Jerman Timur, yang telah empat puluh tahun lebih berpisah dengan saudaranya sesama bangsa Jerman, yang ada di Jerman Barat, untuk bersatu kembali.

Dorongan yang besar dalam diri masyarakat Jerman Timur itu mampu menciptakan endapan psikologis berpuluh-puluh tahun. Endapan psikologis selama berpuluh-puluh tahun itu membentuk ketidaksadaran bersama (collective uncounsciousness), yang kemudian menjadi kesadaran bersama (collective counsciousness). Endapan psikologis tersebut berupa kejenuhan, kemuakan, sekaligus hadirnya harapan bagi dunia baru sebuah bangsa yang diimpikan.

Proses ketidaksadaran bersama kemudian menjadi kesadaran bersama untuk mendesakkan gerakan revolusi di Jerman Timur menemukan titik momentumnya manakala hal itu dipantik dengan bentuk otoriterisme dan represivitas negara Jerman Timur. Otoriterisme dan represivitas-sekali lagi-hanyalah momentum bagi warga Jerman Timur untuk menyalurkan dan menunaikan hasrat politiknya untuk bersatu kembali dengan warga Jerman dibagian barat. Seruan "JERMAN SATU TA-NAH AIR JERMAN SATU TANAH AIR..." yang dikumandangkan pada saat demonstrasi besar-besaran, yakni aksi revolusi damai di Jerman Timur - seperti dalam kutipan data di atas - mampu memberikan gambaran tentang betapa dahsyatnya dorongan politik warga Jerman Timur untuk bersatu dengan saudaranya sesama warga Jerman di bagian Barat.

Jerman sebagai satu bangsa 'nation' yang besar tidak dapat ditolak dalam perjalanan sejarah dunia. Bahkan, mereka merasa sebagai satu ras yang paling unggul di dunia. Ras Aryalah ras yang paling unggul di dunia di atas ras-ras yang lain. Oleh karena itu, hasrat politik untuk bersatu kembali dengan saudaranya sesama warga Jerman Barat merupakan manifestasi dari perasaan politik yang demikian. Hakikatnya adalah ras dan nasionalisme yang dibangun di negara Jerman ialah nasionalisme berbasis ras. ${ }^{13}$ Keinginan atau dorongan politik untuk bersatu kembali juga karena ras. Oleh karenanya, Benjamin Grasmann tokoh penting dalam novel ini yang keturunan yahudi harus 'berlari' ke Yerussalem. Fenomena itu merupakan suatu simbol adanya persoalan yang mendasar dalam penyatuan kembali Jerman itu, yaitu masalah ras.

\section{Rekonstruksi Ideologi}

Persoalan berikutnya yang penting dan segera untuk diselesaikan pasca runtuhnya Jerman Timur dan bersatunya kembali (reunifikasi) Jerman ialah persoalan ideologi. Bagaimanapun, persoalan ideologi merupakan persoalan yang fundamental bagi Jerman yang baru bersatu. Jerman Timur yang selama ini berpaham sosialis dan atas kontrol penuh Uni Sovyet di satu sisi dan di sisi lain Jerman Barat yang berpaham kapitalis dan Pro-Barat akan menjadi masalah tersendiri. Pada saat yang sama merekam dengan saksama harapan ideologis bagi kelompok aktivis revolusi damai juga tidak kalah pentingnya. 
Memori politik bagi warga Jerman Timur yang selama ini mendapatkan tekanan politik berbasis ideologi, juga tidak mudah begitu saja dilupakan. Tekanan politik oleh negara berbasis ideologi itulah yang juga oleh Altuhsser disoroti dengan tajam. Althusser memberikan istilah itu untuk memberikan impresi yang lebih halus yang ia sebut secara khusus sebagai perangkat ideologi negara (state ideological apparatuses) (Barry, 2010:192). Dengan bahasa lain, Althusser ingin menyatakan bahwa terlalu banyak instrument negara berbasis ideologi yang dapat digunakan secara efektif untuk merepresi rakyat.

Oleh karena itu, ideologi dapat menampilkan berbagai wajah dalam bentuk ekpresi politiknya. Simon (1999:86-87) misalnya memberikan paparan tentang pandangan politik Gramsci bahwa ideologi itu tidak dapat dinilai dari kebenaran atau kesalahannya, tetapi harus dinilai dari 'kamanjurannya' dalam mengikat semua kelompok sosial yang berbedabeda ke dalam satu wadah dan dalam peranannya sebagai pondasi atau agen bagi proses penyatuan sosial.

Dalam konteks tersebut, jatuhnya negara Jerman Timur dan disusul dengan bersatunya negera itu dengan Jerman Barat, tidaklah berangkat dari ruang kosong secara ideologis. Secara mendasar, terdapat harapan ideologis rakyat Jerman Timur setelah jatuhnya negara itu dan pasca reunifikasi. Proses tersebut dapat disebut sebagai proses rekonstruksi ideologi. Dalam data novel Rabet, Jatuhnya Jerman Timur karya Martin Jankowski, di bawah ini dapat digambarkan tentang proses rekonstruksi ideologi itu.

Kau akan menjauh dengan melayang di atas jalan setapak kuning, Ben.

Dan jika benar. Mau apa seratus ribu orang-orang itu? Perekonomian bebas. Media massa bebas. Pemilu bebas. Lalu? Kita hidup di negara lain (Jankowski, 2010:226).
Banyak orang yang mengikuti demonstrasi damai tersebut dan sesudahnya melihat bahwa perubahan waktu 1989/1990 merupakan peluang besar bagi pembaruan demokratisasi Jerman Timur, suatu kesempatan politik jalan ketiga, selain kapitalis dan sosialis. Bagi orang-orang yang berharap seperti itu mereka mengalami kekecewaan, baik secara pribadi maupun sejarah menyatunya Jerman Timur ke Jerman Barat pada tanggal 3 Oktober 1990, dimana hari tersebut merupakan perayaan nasional negara Jerman (Kunze dalam Jankowski, 2010:xii)

Jaringan pengikat yang secara ideologis didesakkan oleh para aktivis gerakan revolusi ialah keberaniannya dalam melontarkan gagasan-gagasan substansial tentang bagaimana negara mestinya berposisi. Sebuah posisi negara untuk mencanangkan dengan apa yang disebut oleh aktivis gerakan sebagai perekonomian bebas, media massa bebas, dan pemilu bebas. Itulah titik awal bagaimana para aktivis dalam membangun embrio ideologi barunya. Sebuah embrio ideologi yang digagas dalam rangka merekonstruksi ideologi lama yang dipandang sudah tidak sesuai lagi dengan tuntutan zaman. Sosialisme bagi rakyat Jerman Timur merupakan ideologi yang sudah mengalami korosi di sana-sini. Hanyalah orang-orang yang gila yang menerapkan ideologi itu secara mentah-mentah. Oleh karena itu, dalam praktiknya hanyalah negara yang gila yang menerapkan ideologi tersebut pada rakyat.

Praktik ideologi itu memang gila; sebuah kegilaan ideologis yang membuat siapapun, baik negara dalam konteks institusional, maupun rakyat dalam konsteks individual, semuanya mengalami dan terkena efek kegilaan ideologis itu. Sosialisme Jerman Timur dalam praksisnya juga tidak kalah gilanya, ketika memaksa rakyatnya untuk bermimpi, 
sama dengan mimpi negaranya. Itulah barangkali, sosialisme dapat diletakkan dalam konteks ideologi utopia; suatu konstruksi ideologi yang membangun janji-janji utopis pada rakyat, yang faktanya tidak pernah terwujud.

Pada akhirnya, rakyat mengalami kejenuhan ideologis yang luar biasa dan kemudian membangun harapan politiknya sendiri. Itulah cara rakyat dalam rangka merekonstruksi ideologinya sendiri. Negara bagi rakyat merupakan kekuatan yang masih relevan untuk direposisi dan rakyat oleh karenanya masih logis berada di dalamnya. Persoalan mendasarnya ialah bagaimana negara itu direkonstruksi ideologinya. Menyodorkan pertanyaan ini berarti menyodorkan perubahan secara fundamental dan oleh karena itu disebut revolusi. Rekonstruksi ideologi juga dalam konteks demikian, rakyat berusaha membangun puing-puing ideologi yang telah hancur dan harus segera digantikan dengan ideologi baru yang lebih segar.

Politik jalan ketiga merupakan ideologi alternatif yang dapat menjadi pilihan ketika Jerman telah bersatu. Seperti yang dinyatakan Gidden (2000:74-75) bahwa politik jalan ketiga membantu para anggota masyarakat untuk merintis jalan mereka melalui revolusi utama; yakni globalisasi, transformasi dalam kehidupan personal, menjaga hubungan dengan alam, berbasis keadilan sosial, hak dan kewajiban dijalankan secara seimbang, dan demokrasi. Artinya, bila negara Jerman yang telah direunifikasi itu betul-betul ingin menerapkan politik jalan ketiga, maka dimensi utama dalam politik jalan ketiga tidaklah dapat diabaikan. Negara itu tidaklah dapat menjadi negara yang tertutup seperti pada masa Jerman Timur; sebaliknya, tidak dapat sepenuhnya terbuka (liberal) seperti pada masa kekuasaan politik Jerman Barat. Terdapat nilai mendasar yang dapat menjadi dasar jika negara itu menjadi negara yang akan menerapkan politik jalan ketiga secara konsisten. Yakni, dengan cara berpe- gang pada konservatisme filosofis, yaitu sebagai kerangka nilai yang di satu sisi, meletakkan nilai-nilai sejarah dan tradisi sebagai pijakannya; di sisi lain, bersifat pragmatis dan terbuka terhadap perubahan (Gidden, 2000:78).

\section{Reimajinasi Politik}

Reimajinasi politik terindah bagi warga Jerman Timur untuk hidup secara lebih baik dan beradab betul-betul menjadi kebutuhan mendasar mereka. Kebutuhan akan kebebasan, tidak adanya tindakan represif atas nama apapun, dan terpenuhinya kesejahteraan sosial rakyat merupakan mimpi yang betul-betul dirasakan oleh warga Jerman Timur. Mimpi yang kemudian berubah menjadi imajinasi politik itu memberikan sumber energi yang kuat untuk mendorong terjadinya revolusi secara lebih cepat.

Masyarakat dimanapun pasti diikat dengan mimpi dan imajinasi politik yang demikian itu. Hal itu merupakan aspek fundamental bagi kehidupan manusia. Manusia dimanapun keberadaannya selalu membutuhkan kebebasan, tidak adanya tindakan kekerasan, dan kesejahteraan. Hal Itu merupakan mitos universal yang senantiasa mengiringi laju perkembangan peradaban manusia. Kebebasan, tidak adanya tindakan kekerasan, dan terpenuhinya kesejahteraan merupakan mitos yang bermuara pada dua mitos utama yang bersifat makro, yakni adanya perlindungan dan terpenuhinya rasa aman.

Hal serupa juga terjadi pada warga/ rakyat Jerman Timur; kebebasan, tidak adanya tindakan kekerasan, dan terpenuhinya kesejahteraan menjadi penggerak mereka, karena nilai-nilai dasar humanitas merasa telah dikoyak. Di bawah ini kutipan data yang dapat menggambarkan adanya fenomena imajinasi politik atas lahirnya kebebasan, tidak adanya tindakan kekerasan/represif, dan terpenuhinya kesejahteraan. 
Bahwa dengan akal sehat, setiap orang tidak berani beroposisi melawan slogan buku tulis merah, tidak terbayangkan. Transparansi!nKutipan Rosa Luxemburg pada kuburan Rosa Luxemburg. Kebebasan selalu merupakan kebebasan untuk berpikir berbeda. Rosa Luxemburg dari Berlin Timur yang sudah tiada. Dia diganggu dalam ketenangan abadinya? Pasti segera terjadi aksi bunuh diri secara missal. (Jankowski, 2010:59).

...Surat kabar tanggal satu Mei! Tapi bulan Oktober segera tiba. Tangan kami gemetar ketika melakukannya. Tak seorang pun yang kami kenal berani melakukan itu. Kecuali Mario. Ganti wajib militer dengan kerja sosial, Tillman. Tanpa kekerasan!, Adrian. Bebas bepergian bagi semua orang! Dorothee. Pemilu tanpa hitungan palsu! Gesa. Hidup musim semi Praha!, Aku. Matthias memperhatikan hasil karya kami dan menggaruk-garuk jenggotnya sambil berpikir.

Kami berangkat dengan gelisah, seperti anak-anak yang telah berbuat usil pada gurunya (Jankowski, 2010:174). "Apa yang Anda harapkan dari pemimpin negara yang baru Pak Odin?" "Menurut pendapatku, politik yang baru merupakan tantangan untuk basis pekerjaan yang memuaskan bagi penduduk yang selalu bertumbuh. Suatu tantangan. Penting melakukan segala yang diperlukan untuk menghindari kesalahan yang pernah dilakukan (Jankowski, 2010:240).

Imajinasi politik tentang kebebasan, tidak adanya tindakan kekerasan, dan harapan terpenuhi kesejahteraan, sekaligus menjadi praktik diskursif yang sangat kuat diperbincangkan oleh aktivis gerakan revolusi damai saat itu. Dengan begitu, dunia dan praktik sosial itu dibentuk secara diskursif. Praktik diskursif demikian itu, seperti yang dikemukakan
Foucault menjadi wacana yang mengonstruksi, mendefinisikan, dan memroduksi objek-objek pengetahuan dengan cara yang dapat diterima nalar sekaligus menyingkirkan bentuk nalar yang kurang relevan (Barker, 2005:105). Produksi wacana itu pada proses berikutnya menjadi kekuatan praksis yang menjadi wacana bersama.

Imajinasi politik demikian itu ke depan idealnya menjadi pijakan yang jelas, ke mana arah negara Jerman yang telah terreunifikasi. Sesuatu yang cukup menakutkan terjadi; yakni ketika imajinasi politik seperti itu tidak dapat diwujudkan. Rakyat Jerman, tidak hanya bekas warga Jerman Timur; akan tetapi juga warga Jerman secara keseluruhan akan menjadi kecewa dan kehilangan harapan sebaga bangsa. Dalam kondisi seperti itu, barangkali anomali kemanusiaan sulit untuk dihindari. Tidak hanya, gagal dalam merumuskan terpenuhinya hal-hal substansial dan fundamental sebagai warga; tetapi juga akan berujung pada kegagalan sebagai bangsa.

Seperti yang dinyatakan Anderson (2002:8) bahwa bangsa (nation) adalah sesuatu yang terbayang karena para anggotanya tidak pernah tahu dan kenal antara yang satu dengan yang lain; namun toh, di benak setiap orang yang menjadi anggota bangsa itu hidup sebuah bayangan tentang kebersamaan mereka. Warga Jerman pun diyakini memiliki bayangan tentang kebersamaan mereka. Ikatan kebangsaan yang berbasis pada ikatan ketaksadaran kolektif dan kesadaran kolektif mereka dalam hubungan ras yang sama, meniscayakan pondasi yang kokoh untuk segera merealisasikan imajinasi politik yang terkait dengan kebutuhan fundamental sebagai manusia.

Ikatan kebangsaan yang berbasis ras tidak selamanya dapat dipertahankan kalau kebutuhan fundamental mereka yang bersifat asasi tidak dapat dipenuhi. Imajinasi politik dan proses reimjinasi 
politik itu, sebaliknya akan mengancam bangsa yang telah melakukan reunifikasi. Kebersamaan berada di atas hal yang asasi dalam diri manusia dan ras. Kebersamaan tidaklah dapat menggantikan hal yang asasi (absolut) dalam kehidupan manusia. Reimajinasi politik dalam konteks demikian meniscayakan terpenuhinya hal-hal asasi (absolut) dalam kehidupan dan di atasnya adalah dimensi ras dan solidaritas (kebersamaan).

\section{SIMPULAN}

Novel Rabet, Runtuhnya Jerman Timur karya Martin Jankowski dapat memberikan gambaran beberapa hal yang pokok. Pertama, bahwa hadirnya kesadaran bersama yang melahirkan dorongan yang besar dalam diri masyarakat Jerman Timur dan Jerman Barat untuk hidup bersama, setelah berpuluh-puluh tahun mereka berpisah menyebabkan runtuhnya negara Jerman Timur. Kedua, rekonstruksi ideologi dalam konteks tersebut merupakan manifestasi upaya membangun kembali ideologi yang telah runtuh dan atau diruntuhkan. Politik jalan ketiga merupakan ideologi alternatif yang memungkinkan negara Jerman yang terreunifikasi menapaki jalan ideologinya yang baru. Ketiga, sehubungan dengan reimajinasi politik, reimajinasi politik menjadi titik politik ideal yang dimimpikan-tidak hanya warga Jerman Timur-akan tetapi, juga seluruh warga Jerman. Reimajinasi politik diandaikan secara ideal berada di atas pondasi hal-hal asasi (absolut) dalam kehidupan manusia, dan di atasnya adalah dimensi ras dan solidaritas. Kebebasan, nihilnya tindakan kekerasan, dan terpenuhinya kesejahteraan, merupakan hal asasi yang diidealkan.

Implikasi dari kajian ini, yakni memberikan dorongan bagi bangsa-bangsaseperti halnya Indonesia atas kasus berpisahnya Timor Leste - yang mengalami keterpisahan sebagian wilayahnya diharapkan mampu membuka ruang dan peluang baru bagi bersatunya kembali wilayah tersebut dengan berbagai ikhtiar bangunan kesadaran politik yang dipandang penting dilakukan.

\section{UCAPAN TERIMA KASIH}

Ucapan terima kasih saya sampaikan setinggi-tingginya kepada Prof. Dr. Budi Darma, M.A. yang telah banyak memberi masukan pada tulisan ini.

\section{DAFTAR PUSTAKA}

Anderson, Bennedict. 2002. Imagined Communities. (terjemahan Omi Intan Naomi). Yogyakarta: Insist-Pustaka Pelajar

Barker, Chris. 2005. Cultural Studies: Teori dan Praktik. Yogyakarta: Bentang, terjemahan oleh Tim Kunci Cultural Studies Center, dari judul asli Cultural Studies: Theory and Practice. Sage Publication-London, 2000.

Barry, Peter. 2010. Beginning Theory: Pengantar Komprehensif Teori Sastra dan Budaya. Yogyakarta Jalasutra. Terjemahan oleh Harviyah Widiawati dan Evi Setyarini, Judul asli, Beginning Theory: an Introduction to Literary and Cultural Theory. Manchester: Manchester University Press, 2005.

Brannigan, John. 1999." Introduction: History, Power, and Politics In the Literary Artifact." Edited By Wolfreys, Julian.1999. Literary Theories a Reader and Guide. Washington Squaer, New York: New York University Press.

Darma, Budi. 2004. Pengantar Teori Sastra. Jakarta: Pusat Bahasa Departemen Pendidikan Nasional.

Foucault, Michel.1997. Disiplin Tubuh: Bengkel Individu Tubuh. Penyadur oleh Petrus Sunu Hardiyanta). Yogyakarta: LKIS

Gallagher, Catherine. 1999."Marxisme and The New historicsm." Edited by Wolfreys, Julian. 1999. Literary Theories A Reader and Guide. Washington Squaer, New York: New York University Press. 
Giddens, Anthony. 2000. Jalan Ketiga: Pembaharuan Demokrasi Sosial. Terjemahan Ketut Arya Mahardika. Jakarta: Gramedia.

Gonscharenko, Roman dan Ridwan, Asril. 2009. "Reunifikasi Jerman: Satu Keajaiban Semua Berjalan Damai."http://www.dw-world.de/ dw/article/0,,4862958,-00.html diunduh 29 Jan 2015.

Greenblatt, Stephen. 2005. Renaissance SelfFashioning. Chicago: The University of Chicago Press

Greenblatt, Stephen dan Gallagher, Chaterine. 2000. Practicing New historicsm. Chicago: The University of Chicago Press

Hogan, Patrick Colm. 2007. Philosophical Approaches to the Study of Litarature. University Press of Florida

Jankowski, Martin. 2010. Rabet, Runtuhnya Jerman Timur. Terjemahan Sufriati Tanjung. Jakarta: Penerbit Waktoe.
Miles, Matthew B. dan Huberman, A. Michael. 2009. Analisis Data Kualitatif: Buku Sumber tentang Metode-metode Baru. Jakarta: UIP.

Simon, Roger.1999. Gagasan-gagasan Politik Gramsci. Yogyakarta: Pustaka Pelajar dan Insist.Terjemahan oleh Kamdani dan Imam Baehaqi dari judul asli Gramsci's Political Thaought.

Sugiarti. 2009. "Analisis Kritis New Historicism terhadap Novel Indonesia Modern dalam Kerangka Sejarah Sastra." Jurnal Litera Universitas Negeri Yogyakarta, vol. 8, no 2 2009, hal. 165-178.

Taufiq, Akhmad. 2012. “Kekerasan Orde Baru terhadap Rakyat dalam Teks Sastra Indonesia: Studi New Historicism." Jurnal Kultur Puslit Budaya dan Pariwisata Lemlit Universitas Jember, vol. 4 no. 2 September 2012, hal. 82-93. 